\title{
Klasifikasi Epileptiform dan Wicket Spikes Menggunakan Metode Key-Point Based Local Binary Pattern
}

\author{
Theresia Laura Tayu, Mohammad Nuh dan Muhammad Yazid \\ Departemen Teknik Biomedik, Institut Teknologi Sepuluh Nopember (ITS) \\ e-mail:nuh@ee.its.ac.id
}

\begin{abstract}
Abstrak-Epilepsi adalah gangguan kronis otak disebabkan oleh adanya lepasan muatan listrik abnormal yang berlebihan di neuron-neuron otak secara berlebihan di neuron-neuron otak secara paroksismal dan disebabkan oleh berbagai etiologi, bukan disebabkan oleh penyakit otak akut. Sampai saat ini jumlah penderita Epilepsi mencapai 50 juta di seluruh dunia. Di Indonesia diperkirakan kesalahan diagnosis epilepsi mencapai $20-30 \%$. Salah satu metode yang lazim digunakan untuk pemeriksaan epilepsi adalah dengan melakukan perekaman Electroencephalogram (EEG) kemudian dilanjutkan dengan melakukan diagnosis berdasarkan hasil rekaman sinyal EEG yang dihasilkan. Proses pemeriksaan secara manual oleh dokter ini merupakan proses yang panjang dan melelahkan sehingga tidak jarang menyebabkan terjadinya kesalahan dan over-diagnosis. Salah satu jenis sinyal EEG yang cukup sering salah dianggap sebagai sinyal tanda epilepsi adalah Wicket spikes. Wicket spikes merupakan sinyal wicket yang muncul saat pasien mengalami tidur ringan pada saat pemeriksaan EEG, bentuknya yang mirip sering disalah-artikan sebagai epileptiform sharp wave. Pada penelitian ini, diajukan metode Key-Point Local Binary Pattern dan Support Vector Machine untuk melakukan klasifikasi antara Epileptiform dan Wicket spikes. Metode yang diajukan termasuk pendeteksian Key-Point pada sinyal yang sebelumnya telah melalui proses konvolusi dengan filter gaussian. Local Binary Pattern kemudian akan dihasilkan berdasarkan lokasi Key-Point. Kemudian hasil histogram tersebut akan dimasukkan ke dalam Support Vector Machine untuk diklasifikasikan. Hasil proses klasifikasi berupa hyperplane yang mengklasifikasikan tiga kelas yaitu normal, epileptiform dan wicket spikes. Didapatkan metode yang diajukan memiliki tingkat keberhasilan sebesar $96 \%$ persen untuk klasifikasi pada Epileptiform dan Wicket spikes dan lebih besar dari yang ada pada saat ini.
\end{abstract}

Kata Kunci-Wicket Spikes, Key-Point Local Binary Pattern, dan Support Vector Machine.

\section{PENDAHULUAN}

$\mathrm{E}^{\mathrm{n}}$ PILEPSI adalah kelainan kronis pada otak yang menyerang 50 juta penduduk dunia dan terus bertambah sampai saat ini (WHO, 2018). Menurut definisi oleh Perkumpulan Dokter Spesialis Saraf Indonesia [1], epilepsy disebabkan oleh adanya lepasan muatan listrik abnormal yang berlebihan di neuronneuron otak secara berlebihan di neuron-neuron otak secara paroksismal dan disebabkan oleh berbagai etiologi, bukan disebabkan oleh penyakit otak akut. Penyakit epilepsi ditandai dengan serangan yang terjadi terus menerus dimana serangan tersebut berupa kejang yang terjadi pada sebagian atau seluruh tubuh dan kadang disertai dengan hilangnya kesadaran dan control terhadap kandung kemih. Salah satu cara yang efektif untuk dapat melihat apakah seseorang menderita Epilepsi atau tidak adalah dengan melakukan analisis pada sinyal Electroencephalograph (EEG) dari pasien. Pemeriksaan manual dengan melakukan tanya-jawab terhadap orang di sekitar pasien kurang efektif karena gejala yang diceritakan terhadap dokter dapat berbeda-beda sementara penderita epilepsi tidak tahu bahwa telah mendapat serangan epilepsi.

Pemeriksaan EEG pada pasien akan dilakukan secara terusmenerus dalam jangka waktu lebih dari 24 jam. Hasil dari pemeriksaan tersebut akan diperiksa secara langsung oleh dokter Saraf yang bersangkutan. Proses pemeriksaan sinyal EGG untuk mencari gelombang epilepsi ini sendiri dapat sangat melelahkan bagi dokter yang sudah memiliki banyak pengalaman sekalipun kerena dilakukan secara manual melalui pengamatan visual oleh dokter. Sinyal EEG yang dianalisis oleh dokter yang memiliki pengalaman dan pelatihan berbeda-beda juga mungkin dapat menyebabkan hasil diagnosis yang berbeda-beda dan tidak konsisten. Karena itu sangat dibutuhkan sebuah cara yang dapat menganalisis sinyal EEG secara akurat dan konsisten untuk dapat memastikan diagnosis dari epilepsi yang dihasilkan pasti dan juga sebagai refrensi perawatan yang harus diterima oleh pasien.

Pada proses pemeriksaan yang dilakukan oleh dokter yang dilakukan secara visual dan dalam waktu lama, akan besar terjadinya kesalahan dalam pengamatan visual. Salah satu jenis sinyal EEG yang sering disalah-artikan oleh dokter sebagai sinyal epilepsi adalah sinyal wicket spikes. Penelitian untuk mengklasifikasikan wicket spikes dengan gelombang epilepsi ini memang masih belum marak dilakukan, namun sangat dibutuhkan oleh dokter pada kehidupan praktis. Pada penelitian sebelumnya yang dilakukan oleh Juni Wijayanti pada tahun 2016 [2], digunakan metode Backpropagation Neural Network untuk melakukan klasifikasi antara Wicket spikes dan sinyal Gelombang Epilepsi melalui sinyal EEG. Pada penelitian tersebut didapatkan recognition rate dengan rata-rata $70 \%$. Pada penelitian ini, kesalahan klasifikasi disebabkan oleh ada pemotongan durasi dari gelombang dari wicket spikes. Selain itu, kesalahan pada saat melakukan pemilihan baseline juga merupakan salah satu faktor yang menyebabkan adalah kesalahan klasifikasi pada gelombang lain. Dengan dilakukan penelitian ini, diharapkan bahwa Tugas Akhir ini dapat menghasilkan program deteksi automatis epilepsi dengan tingkat recognition rate dan akurasi yang tinggi sehingga dapat 


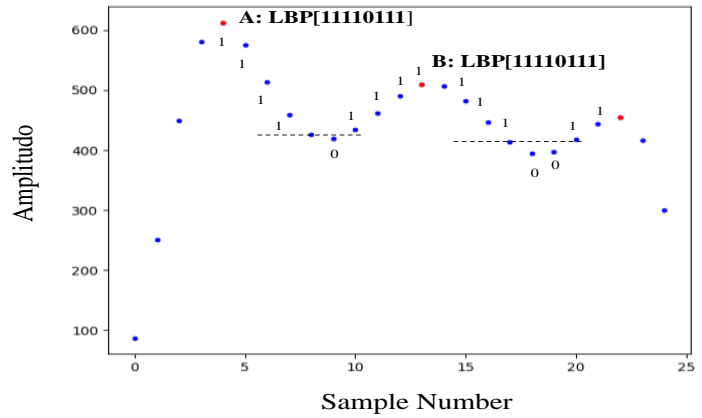

Gambar 1. Proses perhitungan LBP pada 2 Key-Points pada sebuah segmen sinyal EEG ditunjukan pada gambar diatas. Key-Point diwakilkan dengan titik merah, sementara treshold dari setiap KeyPoint ditandai dengan garis putus-putus berwarna hitam.

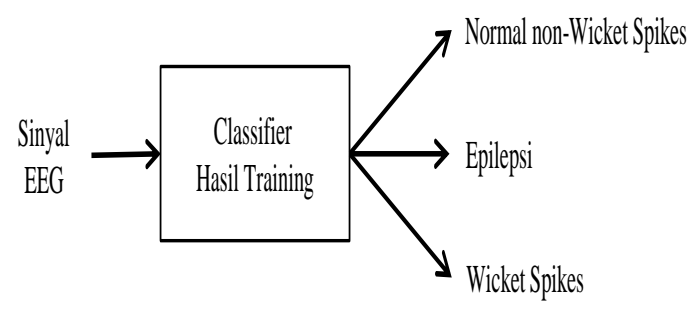

Gambar 3. Diagram blok dari metode pengujian akurasi dari sistem yang dirancang. Menggunakan Ten-Fold Cross Validation, sistem akan dicari nilai akurasinya.

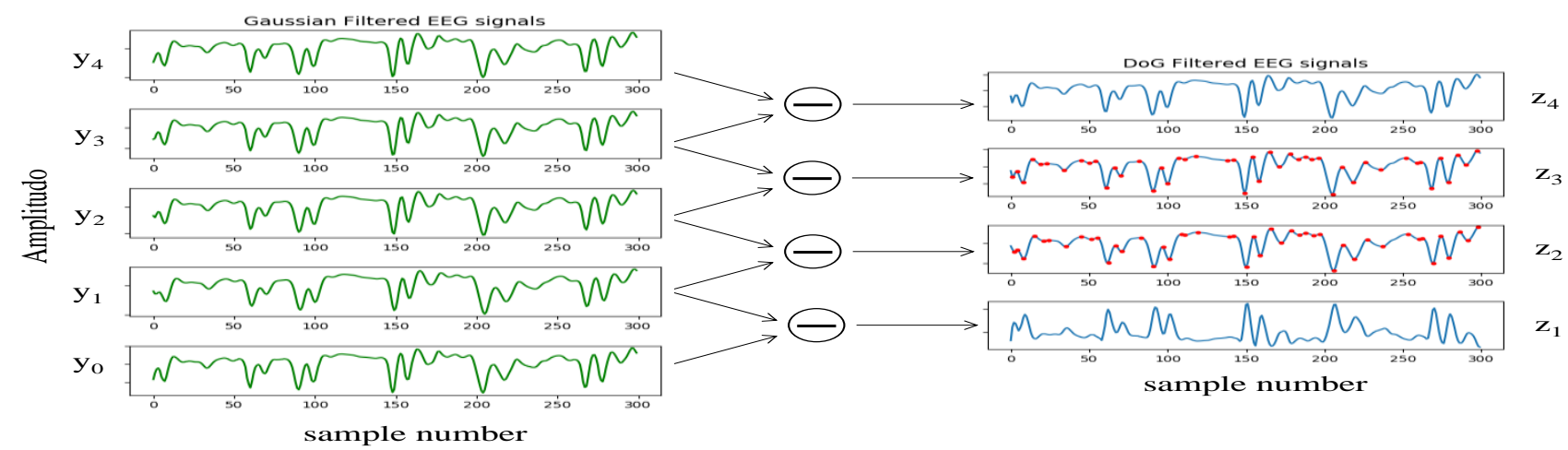

Gambar 2. Skema piramid untuk lokalisasi Key-Point dengan menggunakan proses filter fungsi gaussian dengan 4 nilai yang berbeda. Sinyal yang telah mengalami filter digambarkan pada sisi kiri, dan sinyal DoG yang dihasilkan berdasarkan sinyal tersebut dapat dilihat di sebelah kanan dengan titik merah merepresantaikan key-points terdeteksi.

membantu para dokter saraf dalam proses diagnosis penyakit epilepsi dan menghindari kespalahan diagnosis pada pasien.

\section{II.METODOLOGI PENELITIAN}

\section{A. Deteksi Key-Point pada EEG}

Seperti yang sudah dibahas pada bab sebelumnya, Epileptiform dan Wicket spikes memiliki kemiripan frekuensi dan amplitudo. Yang dapat memunjukan adanya perbedaan antara kedua sinyal tersebut adalah bentuk morfologi visualnya. Dimana epileptiform diikuti dengan focal slowing atau sinyal lambat sementara wicket spikes tidak diikuti dengan focal slowing [3]. Berdasarkan hal-hal tersebut, maka dipilih metode yang dapat menganalisis sinyal berdasarkan morfologi dari sinyal dan juga berbasis pada pattern recognition atau pengenalan pola yang dapat lebih efektif dalam hal klasifikasi antara Epileptiform dan Wicket spikes.

Teknik yang digunakan untuk mendeteksi key-point pada sinyal EEG merupakan teknik yang sudah terbukti sukses dalam bidang pattern recognition. Key-Point adalah nilai extrema yang didapatkan pada sinyal EEG yang sudah mengalami filter dengan fungsi gaussian untuk dapat menghaluskan sinyal secara progresif yang didapatkan dari menaikkan nilai standar deviasi dari fungsi gaussian yang digunakan. Proses ini kemudian akan menghasilkan sederet sinyal EEG yang telah dihaluskan. Langkah selanjutnya dari proses filter ini adalah dengan melakukan pengurangan sinyal EEG terfilter dengan sinyal EEG terfilter yang memiliki nilai standar deviasi fungsi gaussian lebih tinggi. Proses pengurangan ini akan menghasilkan sinyal piramid Difference of Gaussian (DoG). Dimana persamaan discrete-time Gaussian filter yang digunakan adalah:

$$
g\left(t, \sigma^{2}\right)=\frac{1}{\sqrt{2 \Pi \sigma^{2}}} e^{-t^{2} / 2 \sigma^{2}}
$$

Dengan $\sigma$ adalah nilai standar deviasi dari fungsi Gaussian yang akan terus meningkat. Persamaan matetmatika dari proses konvolusi dari dari sinyal EEG $(x(n))$ dengan sebuah set Gaussian filter adalah:

$$
y_{\mathrm{k}}(n)=x(n) * g\left(n, k \sigma^{1}, k=1,2, \ldots M\right.
$$

dimana tanda asterisk melambangkan proses discrete convolution dan $\sigma_{1}$ adalah skala awal dari filter Gaussian. Langkah selanjutnya adalah set-set sinyal hasil konvolusi yang didapatkan bersama dengan sinyal asli EEG $(x(n))$ kemudian akan digunakan untuk mendapatkan piramida sinyal filter DoG melalui persamaan berikut: 


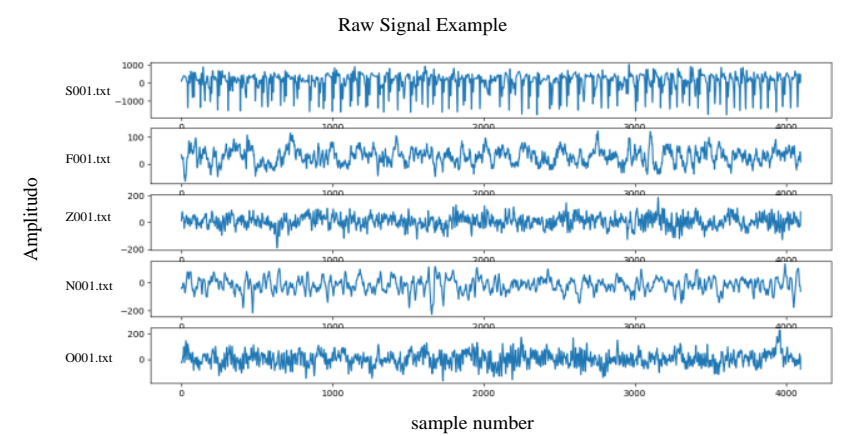

Gambar 4. Hasil plot sinyal data EEG yang bersumber dari Universitas Bonn. Merupakan data hasil dari satu elektroda dan memiliki frekuensi sampling $13 \mathrm{~Hz}$.

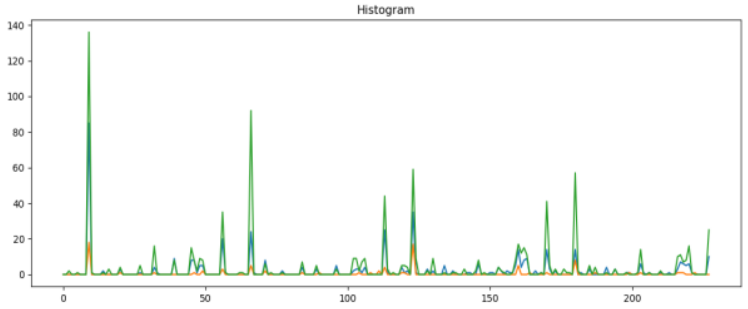

(a)

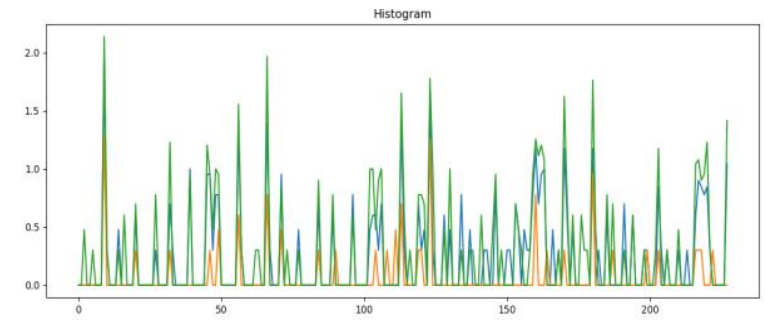

(b)

Gambar 5. Sinyal biru adalah siyal logaritma histogram dari sharp wave epileptiform dan sinyal berwarna orange adalah sinyal wicket spikes. Kemudian sinyal berwarna hijau adalah sinyal Normal. Dimana sinyal (a) adalah analisis tanpa logaritma dan (b) adalah analisis logaritmatik.

$$
z_{\mathrm{i}}(n)=y_{\mathrm{i}}^{-1(n)}-y_{\mathrm{i}}(n), i=1,2, \ldots M
$$

Setelah didapatkan sinyal-sinyal piramid DoG, dapat dimulai proses pencarian nilai Key-Point. Nilai key-point didapatkan dengan mencari nilai extrema (nilai maksimum dan minimum) dari piramida sinyal filter DoG. Nilai Key- Point dapat dihasilkan pada setiap level piramida namun yang dapat digunakan untuk proses selanjutnya adalah semua level kecuali level teratas dan terbawah piramida. Hal ini disebabkan karena kurangnya sinyal pada level atas bawah sinyal [4]. Nilai-nilai Key-Points ini kemudian akan digunakan sebagai dasar untuk membuat histogram dengan metode Local Binary Pattern (LBP).

\section{B. Local Binary Pattern}

Setelah didapatkan nilai-nilai Key-Points, proses selanjutnya adalah mencari representasi fitur untuk proses klasifikasi. Proses ekstrasi fitur dilakukan dengan cara menghitung nilai Local Binary Patern (LBP) pada setiap Key-Points. Secara spesifik, LBP akan dihitung pada Key-Points dari sinyal hasil filter DoG (secara respektif) dan sinyal asli EEG yang memiliki
Tabel 1.

Tabel hasil uji Klasififikasi dari F001.txt, W001.txt dan Z001.txt

\begin{tabular}{llll}
\hline \hline Kelas Uji & Skenario Uji & $\begin{array}{l}\text { Hasil yang } \\
\text { diharapkan }\end{array}$ & $\begin{array}{l}\text { Kesimpul } \\
\text { an }\end{array}$ \\
\hline Mendapatkan & $\begin{array}{l}\text { Data F001.txt } \\
\text { (Epileptiform) } \\
\text { Data W001.txt } \\
\text { hasil }\end{array}$ & Epileptiform & \\
klasifikasi & $\begin{array}{l}\text { Spicket Spikes) } \\
\text { Data }\end{array}$ & Normal & Berhasil \\
& Z001.txt(Normal) & Normal & \\
\hline \hline
\end{tabular}

Tabel 2.

Tabel kelas dan Clasification Data yang digunakan pada metode yang diusulkan.

\begin{tabular}{cl}
\hline \hline Classification Problem & Classes \\
\hline \multirow{2}{*}{1} & Normal $(\mathrm{Z}, \mathrm{O})$ \\
& Epileptiform $(\mathrm{N}, \mathrm{F})$ \\
2 & Normal $(\mathrm{Z}, \mathrm{O})$ \\
& Wicket spikes $(\mathrm{W})$ \\
3 & Epileptiform $(\mathrm{N}, \mathrm{F})$ \\
& Wicket spikes (W) \\
& Normal, Epileptiform (ZONF) \\
& Wicket spikes (W) \\
\hline \hline
\end{tabular}

Tabel 3.

Tabel tingkat keberhasilan metode yang diajukan

\begin{tabular}{|l|l|l|l|}
\hline Data & Jumlah & $\begin{array}{l}\text { Terklasifikasi } \\
\text { benar }\end{array}$ & $\begin{array}{l}\text { Keberhasilan } \\
{[\%]}\end{array}$ \\
\hline Wicket Spikes & 25 & 23 & 92 \\
\hline Epileptiform & 25 & 25 & 100 \\
\hline Total & 50 & 48 & 96 \\
\hline
\end{tabular}

nilai poin yang sama dengan Key-Points. Secara umum, proses perhitungan LBP pada Key-Points pada sinyal $f(n)$ dinyatakan secara matematis dengan: LBP

$[F(i)]=\sum_{j-0}^{3} S[f(i+j), f(i+4)]+\sum_{j-5}^{8} S[f(i+$

$j), f(i+4)] 2^{\mathrm{j}-1}$

dimana fungsi $S$, dengan $f(i)$ dan $f(j)$ sebagai parameter input adalah

$$
S[f(i), F(i)]= \begin{cases}1, & f(i) \geq f(i) \\ 0, & f(i)<f(i)\end{cases}
$$

Melihat persamaan (4), $i$ mewakili indeks sampel dari KeyPoints dimana perhitungan LBP dilakukan. Seperti yang dapat dilihat pada persamaan (4), LBP dihasilkan dengan menjadikan sampel yang berjarak empat sampel sebelah kanan dari KeyPoint sebagai center of sample. Center of Sample akan berperan sebagai batas bagi empat sampel setelah dan sebelumnya dalam menentukan besar nilai biner yang akan mewakilinya. Apabila sampel terletak dibawah batas, maka akan diwakili dengan nilai biner 0 dan apabila sampel terletak diatas batas maka akan diwakili dengan nilai biner 1 . Proses ini akan menghasilkan 8 deret kode biner seperti yang dapat dilihat pada Gambar 1. Nilai desimal dari setiap kode biner ini adalah yang dinamakan sebagai LBP. Pada penelitian ini, akan digunakan fitur histogram dari LBP untuk proses klasifikasi dari sinyal EEG. Nilai LBP yang digunakan adalah hanya nilai LBP yang bersifat uniform pattern. Uniform pattern adalah dimana hanya terdapat maksimal dua kali transisi dari nilai 1 ke 0 atau 0 ke 1 pada kode biner. Semua nilai yang bersifat uniform pattern akan 
dikelompokkan menurut nilainya, sementara nilai yang bersifat non-uniform pattern akan dikelompokkan menjadi satu. Perlu diperhatikan bahwa LBP harus dihitung menurut Key-Point pada masing masing level piramida DoG dapat dilihat pada Gambar 2. Karena Key-Points tidak dapat dihitung pada level paling atas dan bawah piramida, proses ini akan menghasilkan satu set histogram berjumlah $M-2$ untuk sinyal hasil filter DoG. Satu set histogram lainnya didapatkan dari melakukan perhitungan LBP pada sinyal asli EEG $(x(n))$ yang nilai poinnya sesuai dengan Key-Points. Kemudian kedua set histogram ini akan menjadi satu rangkaian fitur histogram yang kemudian akan diklasifikasi menggunakan metode Support Vector Machine.

\section{Klasifikasi}

Klasifikasi pada penelitian ini dilakukan dengan menggunakan Support Vector Machine yang sudah tersedia di library sklearn pada Python.

\section{D.Pengujian Akurasi dengan Menggunakan Ten Fold Cross Validation}

Selanjutnya akan diuji akurasi dari algoritma yang telah dibuat. Akurasi adalah kesamaan atau kedekatan suatu hasil pengukuran dengan angka atau data yang sebenarnya. Cross Validation adalah metode statistik yang akan digunakan untuk mengevaluasi kinerja Classifier yang dibuat dimana data dipisahkan menjadi dua buah subset yaitu data training dan data testing/validasi dapat dilihat pada Gambar 3. Algoritma yang dilatih oleh proses learning akan divalidasi dengan data subeset testing/validasi. Selanjutnya jenis pemilihan $\mathrm{CV}$ akan bergantung pada ukuran dataset dimana CV digunakan karena dapat mengurangi waktu komputasi dengan tetap mejaga keakuratan estimasi. Pada Ten-Fold Cross Validation, besar CV yang digunakan sebesar 10. Sehingga akan didapatkan 10 subset data untuk mengevaluasi kinerja model dan algoritma. Dimana masing-masing dari 1 subset data tersebut akan menjadi 9 fold untuk latihan dan 1 fold untuk pengujian. Perhitungan matematis dari Ten-Fold Cross Validation digambarkan sebagai berikut: Misalkan $x_{l}^{k}$ dan $y_{l}^{k}$ dengan $(k=$ $1,2,3, \ldots, 10)$ dan $(1=1,2,3, \ldots, \mathrm{N})$ menjadi nilai target dan nilai prediksi dari pengamatan data $l$ dalam subset $k$. Maka kinerja model atau algoritma dari ini dapat diperkirakan dengan mean squared error cross-validation (MSECV) sebagai berikut:

$$
M S E C V=\frac{1}{10} \frac{1}{N_{c v}} \sum_{k=1}^{10} \sum_{l=1}^{N_{c v}}\left(x_{l}^{k}-y_{l}^{k}\right)^{2}
$$

Kemudian digunakna CV untuk memilih model yang sesuai dengan membandingkan nilai MSECV. Model atau algoritma yang terbaik dipilih jika dan hanya jika memiliki nilai MSECV terendah dibandingkan dengan nilai yang lain. Kemudian misal $x_{m}^{v a l}$ dan $y_{m}^{v a l}$ adalah nilai target dan nilai prediksi untuk data validasi dan $\mathrm{M}$ adalah jumlah data validasi. Dapat digunakan mean quare error (MSE) untuk didapatkan validasi model tarbaik.

\section{E. Pengujian Tingkat Keberhasilan}

Pada pengujian tingkat keberhasilan dilakukan dengan cara melakukan percobaan pengulangan lima kali pada program klasifikasi untuk setiap file berlabel. Dengan catatan bahwa 1 berarti nilai sesuai dengan hasil klasifikasi sesuai dengan label yang ada dan 0 berarti label tidak sesuai dengan label yang ada. Hasil dari total percobaan ini kemudian akan dihitung tingkat keberhasilan dengan menggunakan rumus:

$$
y=\frac{\sum_{i=1}^{n} f_{i}-y_{i}}{n} \times 100 \%
$$

dimana $y$ adalah prosentase tingkat keberhasilan, $f_{i}$ adalah nilai yang diharapkan. $y_{i}$ adalah nilai yang didpatkan dari klasifikasi dan $n$ adalah banyaknya percobaan yang dilakan pada satu data. Setelah didapatkan besaran persenan dari percobaan yang dilakukan terhadap data terlabel, maka akan kemudian akan dicari standar deviasi dan mean absolute error dari hasil prosentase yang didapatkan. Dimana rumus standar deviasi yang digunakan adalah

$$
s=\sqrt{\frac{\sum_{i=1}^{n}\left(X_{i}-\bar{x}\right)^{2}}{n-1}}
$$

Sedangkan rumus Mean Absolute Error (MAE) yang digunakan adalah

$$
M A E=\frac{1}{n} \sum_{i=1}^{n}\left|f_{i}-y_{i}\right|
$$

dengan $f_{i}$ adalah nilai yang diharapkan dan $y_{i}$ adalah nilai yang dihasilkan oleh algoritma yang diajukan. Dan nilai $\mathrm{n}$ adalah banyak nilai absolute error yang dihasilkan.

\section{PENGUJIAN SISTEM}

\section{A. Deskripsi Dataset}

Pada penelitian kali ini salah satu data yang akan digunakan adalah dataset yang disediakan oleh Universitas Bonn, Jerman dan dapat diakses oleh publik. Dataset ini berisi sinyal EEG yang meliputi subyek sehat dan seorang pasien (saat sedang terkena serangan dan saat sedang tidak terdapat serangan). Rekaman EEG dari subyek sehat diambil pada dua kondisi yakni saat mata tertutup dan mata terbuka. Data yang didapatkan dari subjek sehat diambil dalam dua kondisi dengan anotasi $\mathrm{Z}$ dan $\mathrm{O}$ dapat dilihat pada Tabel 2. Setiap dataset memiliki 100 rekaman sinyal EEG. Dalam dataset juga terdapat dataset $\mathrm{N}$ dan $\mathrm{F}$ yang merupakan data dari pasien epilepsi yang direkam saat tidak terjadi serangan, sementara data dengan anotasi $\mathrm{S}$ adalah hasil perekaman sinyal dari pasien saat terkena serangan. Contoh data yang berasal dari Uniersitas Bonn dapat dilihat pada Gambar 4. Dalam penelitian kali ini dalam rangka untuk mengevaluasi perfomance dari metode yang diusulkan, diusulkan tiga buah masalah klasifikasi yakni, Normal (N) dan Epileptiform $(\mathrm{E}), \operatorname{Normal}(\mathrm{N})$ dan Wicket spikes(WS) dan Epileptiform(E) dan Wicket spikes (W). Kelas Normal(N) 
diambil dari subset $\mathrm{Z}$ dan $\mathrm{O}$, kelas Epileptiform didapatkan dari kelas $\mathrm{N}$ dan $\mathrm{F}$ dan kelas Wicket spikes didapatkan dari data yang berasal dari Rumah Sakit Universitas Airlangga. Dalam mendapatkan data wicket spikes, digunakan data yang sudah terkumpul oleh Rumah Sakit Universitas Airlangga. Dataset terdiri merupakan dataset perekaman EEG digital dari beberapa pasien. Proses akuisisi sinyal EEG yang dimaksud dengan menggunakan 16 elektroda yang mengikuti sistem internasional 10-20. Dataset yang digunakan sudah terlabel oleh dokter ahli saraf dan didapatkan dari beberapa set pasien. Data-data ini akan digunakan untuk untuk mengevaluasi perfomansi metode yang diajukan untuk Classification task kedua,ketiga dan keempat.

\section{PEMBAHASAN}

\section{A. Analisis Hasil Histogram}

Pada analisis histogram, dilakukan analisis perbandingan antara dua sinyal yakni sinyal epileptiform dan sinyal wicket spike. Pada analisis pertama dilakukan analisis terhadap hasil histogram dari epileptiform dan Wicket spikes. Pada tahap ini sudah dapat dilihat pada bentuk histogram yang dihasilkan pada Gambar 5 (a) bahwa terdapat nilai nilai histogram sama pada nilai-nilai Local Binary Pattern tertentu. Hal ini membuktikan bahwa benar secara morfologis, bentuk wicket spikes dan epileptiform memiliki bentuk yang hampir mirip. Kemudian apabila dianalisis lebih lanjut, akan terlihat bahwa meskipun demikian, akan terlihat perbedaan nilai pada titik titik tersebut walaupun bernilai sangat kecil. Sehingga dilakukan analisis logaritma terhadap hasil histogram dari hasil perhitungan Local Binary Pattern. Pendekatan logaritma dipilih untuk dapat melihat jelas nilai nilai yang sebelumnya terlalu kecil sehingga dianggap 0 menjadi nilai yang lebih jelas. Melalui analisis yang dilakukan secara logaritmik ini dapat dilihat secara jelas, bahwa secara morfologi, epileptiform (sharp wave) dan sinyal WicketSpikes jelas sekali memiliki karakteristik nilai histogram yang berbeda dengan berbedanya bentuk morfologis walaupun memang memiliki kemiripan pada nilai nilai tertentu seperti yang digambarkan pada Gambar 4. Pada gambar tersebur dapat dilihat bahwa memang pada nilai nilai histogram tertentu puncak nilai baik dari sinyal sharp waves dan Wicket spikes memiliki karakteristik yang mirip sehingga, dapat metode analisis morfologi dapat dibilang tepat untuk menganilisis perbedaan antara Wicket spikes dan Epileptiform Sharp Waves.

Dari hasil analisis ini dapat dilihat bahwa jumlah-jumlah frekuensi pada nilai LBP tertentu yang berbeda namun memiliki kemiripan jumlah, dapat dijadikan pengetahuan dasar untuk membantu pengguna untuk membedakan hasil histogram dan morfologi dari Wicket spikes dan Epileptiform.

Pada pemeriksaan yang dilakukan oleh dokter, ditemukan masalah berupa sulitnya membedakan salah jenis epileptiform benign normal yang bernama wicket spikes. Pada penelitian yang dilakukan sebelumnya pada tahun 2017 metode learning dengan menggunakan Backpropagation Neural Network digunakan untuk dapat melakukan klasifikasi terhadap epileptiform dan wicket spikes. Pada penelitian tersebut, dihasilkan recognition rate sebesar $76.6 \%$ dimana masih terdapat beberapa kesalahan dalam melakukan klasifikasi yang bertugas membedakan epileptiform sharp waves dengan wicket spikes. Seperti yang telah dibahas pada bagian 5.3 dan 5.4 metode yang diajukan pada penilitian kali ini dapat memberikan informasi mengenai perbedaan karakteristik histogram LBP dari epileptiform sharp waves dan wicket spikes. Dengan melakukan pengamatan terhadap kedua hasil histogram ini, kemudian dapat ditemukan faktor pembeda dari histogram LBP kedua sinyal tersebut sehingga dapat dengan mudah dilakukan pengamatan terfokus hanya pada nilai-nilai tersebut untuk menentukan apakah sinyal yang diragu-ragukan tersebut merupakan sinyal epileptiform atau Wicket spikes. Kemudian pada hasil analisis classifier yang dilakukan pada bagian 5.3. dibuktikan tingkat keberhasilannya melalui beberapa percobaan algoritma ini.

\section{B. Analisis Hasil Classifier Epilleptiform dan Wicket Spikes}

Tenfold cross validation umum digunakan untuk mengukur perfomance seperti akurasi (ACC), sensitifitas (SEN), dan specificity (SPE). Dalam metode yang digunakan terdapat dua paramater yang akan mempengaruhi besar-kecilnya akurasi yakni besarnya standar deviasi yang digunakan dalam fungsi Gaussian dan juga jumlah level yang digunakan dalam piramid DoG. Dalam penelitian ini besaran nilai standar deviasi yang digunakan adalah 0.5 terus bertambah sesuai dengan kelipatanya linear dengan jumlah level piramida DoG yang ingin digunakan yakni 0.5, 1, 1,5 dan 2. Berdasarkan penelitian sebelumnya [3] dimana Key-Point yang bisa digunakan hanyalah Key-Point yang tidak berada di paling atas dan paling bawah Piramid. Pada perhitungan hasil proses akurasi akan digunakan empat jenis classification task untuk diukur akurasinya. Setelah didapatkan level piramid dengan jumlah 4 dipilih karena akan dapat digunakan dua informasi Key-Point yang menyimpan informasi penting mengenai lokasi-lokasi morfologi representatif dari sinyal EEG yang diolah [3]. Sehingga hasil pengukuran akurasi, sensitifitas dan specifity untuk empat tugas klasifikasi yang berbeda. Kelas klasifikasi dengan 50 kasus untuk setiap kelasnya. Berdasarkan pembagian ini, masing masing kelas klasifikasi akan memiliki definisi masing-masing dalam penentuan akurasinya. Dimana untuk kelas klasifikasi yang pertama nilai True positive (TP) adalah jumlah kasus yang secara benar terindifikasi sebagai normal. False positive (FP) adalah jumlah kasus yang secara tidak benar/keliru terindifikasi sebagai normal, True negative (TN) adalah jumlah kasus yang secara benar terindifikasi sebagai Epileptiform, False negative (FN) adalah jumlah kasus yang secara tidak benar/keliru terindifikasi sebagai Epileptiform. Pola ini terus digunakan sesuai dengan kelas Tabel 1 yang digunakan pada kelas klasifikasi yang dijalankan. Kemudian, hasil nilai TP, FP, TN dan FN ini akan dijadikan dasar sebagai perhitungan akurasi untuk mencari nilai akurasi dari dua kelas diuji.

Kemudian diukur juga tingkat keberhasilan dari Classifier yang dihasilkan dari algoritma yang dibuat, dimana tingkat keberhasilan didapatkan melalui persen nilai hasil klasifikasi yang sesuai dengan hasil yang dilabel atau diekspektasikan. Dari gabungan 50 data wicket spikes dan epileptiform, sebesar 
96\% atau 48 data berhasil diklasifikasikan sesuai dengan labelnya masing masing. Pada Tabel 3 dapat dilihat detail hasil percobaan dan tingkat keberhasilan yang didapatkan oleh metode yang diusulkan. Hasil recognition rate dari metode yang diusulkan dibandingkan dengan metode yang diusulkan sebelumnya oleh Juni Puspita adalah $76.12 \%$ dibandingkan dengan 96\% [2] . Dapat dilihat bahwa nilai akurasi yang dihasilkan oleh metode yang diajukan untuk tugas klasifikasi Epileptiform - Wicket spikes menghasilkan hasil yang lebih tinggi dibandingkan dengan penelitian sebelumnya.

\section{V.KESIMPULAN/RINGKASAN}

Pada penelitian ini, diajukan metode Key-Point Based Local Binary Pattern yang digunakan untuk melakukan klasifikasi terhadap Epileptiform dan Wicket spikes dimana dapat membantu menghilangkan keraguan-raguan dalam proses diagnosis yang dikarenakan kemiripan dua bentuk sinyal tersebut. Metode yang diajukan adalah Key-Point Based Local Binary Pattern dan Support Vector Machine. Metode yang diajukan juga dibandingkan dengan metode klasifikasi yang sudah ada saat ini. Klasifikasi yang sudah ada menggunakan metode Backpropagation Neural Network dan memiliki recognition rate (keberhasilan) sebesar $76,12 \%$. Sedang tingkat keberhasilan dalam hal recognition rate yang dihasilkan dalam metode yang diajukan kali ini adalah $96 \%$. Sehingga metode ini terbukti memiliki tingkat keberhasilan lebih tinggi dibandingkan dengan metode sebelumya.

\section{DAFTAR PUSTAKA}

[1] "Pedoman Tatalaksana Epilepsi 2014 (Perdossi)," 2014. https://www.scribd.com/doc/236670695/Pedoman-Tatalaksana-Epilepsi2014-Perdossi.

[2] J. W. Puspita, A. I. Jaya, and S. Gunadharma, "Classification of EpileptiNetwork," in AIP Conference Proceedings, Mar. 2017, vol. 1825, no. 1, p. 020018, doi: 10.1063/1.4978987.

[3] J. Stern, Atlas of EEG Pattern, 2nd ed. Los Angeles: Wolters Kluwer, 2015.

[4] A. K. Tiwari, R. B. Pachori, V. Kanhangad, and B. K. Panigrahi, "Automated Diagnosis of Epilepsy Using Key-Point-Based Local Binary Pattern of EEG Signals," IEEE J. Biomed. Heal. Informatics, vol. 21, no. 4, pp. 888-896, Jul. 2017, doi: 10.1109/JBHI.2016.2589971.

[5] V. Bajaj and R. B. Pachori, "Classification of Seizure and Nonseizure EEG Signals Using Empirical Mode Decomposition," IEEE Trans. Inf. Technol. Biomed., vol. 16, no. 6, pp. 1135-1142, 2012, doi: 10.1109/TITB.2011.2181403. 